\title{
A Visit to the British Nature Reserve on the Farne Islands
}

\author{
by MARGARET BELCHER, Regina
}

The visitor to Great Britain is indebted to the National Trust which does a splendid work in preserving historic sites and "nature reserves." Lucy Murray and I had a fine demonstration of the Trust's work this summer when we spent a few hours on the Farne Islands off the coast of Northumberland. The Farne Islands were purchased some years ago by the Farne Island Association to prevent commercial exploitation of an area where great colonies of seabirds nest each year. In 1925, the islands were formally handed over to the National Trust and bird watchers are now posted on the islands by the Trust.

We visited the Farnes on June 14 in the nesting season, and were consequently allowed to land on only two of the islands. The twenty minutes on the first island, the Inner Farne, were all too short as we were trying to see what birds were there and to take some photographs of them. We actually overstayed our time and had to be rowed out to the fishing launch that had brought us to the island. Although we knew that our shore leave should have been cancelled, we were allowed to land again on Staple Island!

St. Cuthbert's Cove on the Inner Farne where we first landed had a large breeding colony of Arctic Tern. The birds screamed over our heads as they left their nests on the rocky shore and in the grassy meadows above us. Sandwich, Common and Roseate Terns, the watcher told us, also nest on the Farne Islands; but the Arctic Tern that we saw on the Inner Farne is the most abundant species.

On the Inner Farne we saw Shag, Kittiwakes, a few Razorbills, and our first Puffins-the Puffins perched on the rocks or swimming in great numbers on the sea below. Then, on the open ground, sheltered only by short grass, sea campion and thrift, were the nests of the famous Eider Ducks known locally as St. Cuthbert's ducks because St. Cuthbert fed them when he lived as a hermit on the Inner Farne.
Off Staple Island, the stacks known as the Pinnacles were unbelievably crowded with Guillemots. On those rocks and on the rocky ledges of Staple Island itself, the great numbers of nesting Kittiwake', Shag and Guilemont would have delighted any photographer interested in birds. Among these birds, the "bridled" form of the Common Guillemot was pointed out to us by a National Trust watcher.

The grassy hilltop of Staple Island was riddled with Puffins' burrows, and we stopped briefly to watch the birds enter and leave them. Where grass gave way to bare rocks, little Rock Pipits could be seen rising into the air and one of our party came upon a nest.

On the Wamses where we did not land, we could see the Herring and Black-billed Gulls and the Cormorants that nest there. In order to protect other seabirds from the predations of the Herring Gull, the watchers comb the islands and collect their eggs.

As we passed the Longstone, the island from which Grace Darling and her father made their heroic rescue of survivors of the shipwrecked "Forfarshire," Oyster-catchers were hunting food in the sand. These black and white waders are as conspicuous in appearance as our Avocets. We didn't see Ring-billed Plovers here (they are supposedly rather rare on the Farnes) but I had noted one previously on the Inner Farne. It was on the Longstone, too, that we saw adult and young Grey Seal sunning on the rocks and then slipping into the water at our approach.

This brief visit to the Farnes gave us the opportunity to see nesting colonies of seabirds for the most part quite unknown to us of the Canadian prairies. It was really a surprise to us to be allowed to land on the islands in nesting season. Landing permits were required, it is true, but it seemed that small parties could easily obtain them provided they respected the Trust's regulations. 